\title{
COMUNICAÇÃO BREVE A five year follow-up study of 11 patients with bipolar
} disorder

\author{
Seguimento de 11 pacientes com transtorno bipolar por cinco anos \\ Fernanda Novis',2, Elie Cheniaux, ${ }^{1,2}$ Jesus Landeira-Fernandez ${ }^{3}$, Marcio Versiani
}

\section{Palavras-chave \\ Transtorno bipolar, incapacidade, \\ funcionamento, estudos prospectivos.}

\section{Keywords}

Bipolar disorder, disability, functioning, prospective studies.

\section{RESUMO}

Objetivo: Estudar a evolução de longo prazo do transtorno bipolar (TB). Método: Onze pacientes com TB do tipo I foram acompanhados de forma naturalística em um ambulatório universitário por cinco anos. Foram utilizadas a Escala de Impressão Clínica Global (versão TB), para a avaliação dos episódios afetivos, e a Escala de Evolução Strauss-Carpenter, para a avaliação do funcionamento sócio-ocupacional. Resultados: A maioria dos pacientes esteve sintomática a maior parte do tempo, apresentando predominantemente quadros depressivos. Em média, os pacientes ficaram em eutimia durante $47,7 \%$ do tempo. Apesar do baixo índice de hospitalização, a maioria dos pacientes apresentou funcionamento deficiente quanto às atividades sociais e ocupacionais. Pior evolução quanto à vida ocupacional foi associada a menor número de meses em eutimia e a maior duração dos episódios depressivos. O número total de meses em eutimia se correlacionou negativamente com a idade e a duração da doença. Conclusão: Apesar do tamanho reduzido da amostra, nossos resultados parecem corroborar os da literatura. A maioria dos pacientes apresentou evolução desfavorável, com longos períodos sintomáticos, especialmente com episódios depressivos, e importante comprometimento sócio-ocupacional.

\begin{abstract}
Objective: To study the long-term follow-up of patients with bipolar disorder (BPD). Method: Eleven outpatients with BPD type I were followed up naturalistically for five years at a university teaching hospital. The Clinical Global Impression Scale (BPD version) was used to evaluate the occurrence of affective episodes, and the Strauss-Carpenter Outcome Scale was used to evaluate social and occupational functioning. Results: The majority of patients were symptomatic most of the time, with predominantly depressive episodes. Overall, patients remained euthymic a mean of $47.7 \%$ of the time. Despite a low rate of hospitalization, social and occupational functioning was poor in the majority of patients. A poor disease course with respect to work-related functioning was associated with fewer months of euthymia with a longer duration of depressive episodes. The total number of months of euthymia negatively correlated with the patient's age and disease duration. Conclusion: Despite the small sample size, the present findings appear to corroborate previous studies on the evolution of BPD. Most of the patients had a poor disease course, with long symptomatic periods, particularly depressive episodes, and significantly impaired social and occupational functioning.
\end{abstract}

1 Federal University of Rio de Janeiro, Institute of Psychiatry (IPUB-UFRJ).

2 State University of Rio de Janeiro (UERJ).

3 Pontifical Catholic University of Rio de Janeiro (PUC-Rio), Psychology Department, and Estácio de Sá University, Campus Akxe, Psychology Course.

Endereço para correspondência: Elie Cheniaux

Rua Santa Clara, 50/1213, Copacabana

22041-012 - Rio de Janeiro, RJ, Brazil

Telephone/Fax: +55 (21) 2547-0670

E-mail:echeniaux@gmail.com 


\section{INTRODUCTION}

The first descriptions of what is now referred to as bipolar disorder (BPD) emphasized the more benign nature of the disease compared with schizophrenia. Falret highlighted the existence of an "interval of lucidity" within circular madness (i.e., the return of a normal affective state between the states of mania and melancholy)'. Kraepelin claimed that manicdepressive insanity differed from dementia praecox because of the absence of a progressive course of deterioration'. In fact, the diagnosis of BPD disorder implies a more favorable prognosis than schizophrenia ${ }^{2}$. However, several recent studies have shown that BPD prognosis is not as favorable as it was believed some decades ago ${ }^{3-5}$.

The present study described the first five years of followup of 11 patients with a BPD type I diagnosis treated as outpatients at a university teaching hospital in Rio de Janeiro, Brazil. Scales for the evaluation of symptoms and psychosocial function were regularly applied to analyze the long-term course of the disease in these patients.

\section{METHODS}

\section{Sample}

The study was conducted in the outpatient center for bipolar disorder research at the Institute of Psychiatry, Federal University of Rio de Janeiro, Brazil. To be included in the study, patients had to be at least 18 years of age and to meet the criteria defined by the Diagnostic and Statistical Manual of Mental Disorders (DSM-IV) ${ }^{6}$ for the diagnosis of BPD type I evaluated using the Structured Clinical Interview for DSM-IV Disorders (SCID) ${ }^{7}$. Individuals were excluded only if they did have no attend consultations at least once per month for a period of five years. All participants gave written informed consent before enrolling in the study, which was approved by the local ethics committee.

This report refers to the first 11 patients to reach the established five year duration of follow-up with the regularity required by the research protocol. Of these, nine patients were female, and two were male. Ages ranged from 29 to 70 years at the beginning of treatment, with a mean age of 41.5 years ( $S D=12.3$ years). The mean age at onset of the disease was 28.0 years (SD $=8.6$ years; range, 15 to 43 years). The duration of the disease ranged from 1 month to 40 years, with a mean of 13.7 years (SD = 6.1 years). Seven of the eleven had prior psychotic episodes, five of these with moodincongruent delusions or hallucinations. There was also a case of prior postpartum depression. The mean number of previous psychiatric hospitalizations was 2.1 (SD = 1.7), with only two patients never hospitalized and one admitted to a hospital five times. Two of the patients had a previous history of suicide attempts. Four patients had comorbid psychiatric disorders. One presented agoraphobia without panic disorder, and three had obsessive-compulsive disorder. One of these three also had a specific phobia.

\section{Clinical evaluation}

The patients were followed up naturalistically using the Clinical Global Impressions - Bipolar Disorder version (CGI-BP) ${ }^{8}$ as an evaluation instrument at each visit. Only the first item of this scale was used. Scores on this scale ranged from 1 (normal) to 7 (very severely ill). The criterion used to define euthymia was a score $<3$ (mildly ill), both for mania and depression. A cut-off score $\geq 3$ was used to indicate the presence or absence of manic and depressive syndrome. The criterion used to define episodes was score $\geq 3$ for depression and $<3$ for mania, to define depressive episode; score $<3$ for depression and $\geq 3$ for mania, to define manic episode, and score $\geq 3$ for both, to define mixed episode.

Additionally, the first three items of the Strauss-Carpenter Outcome Scale (SCOS) ${ }^{9}$ were employed annually to evaluate patients over the previous 12 months. For each of these three items, which estimate non-hospitalization (item 1), social activity (item 2), and employment (item 3), a score ranging from 0 to 4 was assigned, with higher scores corresponding to better evolution. All patients were evaluated by the same psychiatrist (EC) throughout the five year study. The fourth item was not used because it deals with the assessment of symptoms over the last month, best assessed by using the CGI-BP.

\section{RESULTS}

Only two patients remained euthymic at least $75 \%$ of the time. Other three were symptomatic for no more than 25 days. Six of the 11 patients remained symptomatic more than $50 \%$ of the time. Two patients were euthymic for a maximum of six months in the five year period. Overall, the patients were euthymic an average of $47.7 \%$ of the time.

Eight patients spent more time in a depressive state than in a manic state, whereas three patients spent more time in a manic state than in a depressive state. Depression accounted for $24.4 \%$ of the time, whereas mania accounted for $15.5 \%$ of the time, and a mixed state accounted for $12.3 \%$ of the time. Overall, when patients were symptomatic, depressive episodes were longer than manic episodes. Then, on average, each patient had 5.5 manic episodes, 5.0 depressive episodes, and 3.5 mixed episodes.

All of the patients had psychotic symptoms at some point during the five year follow-up period. Four patients were admitted to a hospital. Of these, one was admitted once, two were admitted twice, and one was admitted three times. Despite this, there were no cases of suicide attempts during 
this time. Two of the nine women in the study became pregnant during the five year period. Of these two, one became pregnant twice during the follow-up period. For this reason, these two women were the only participants who discontinued their medication for a period of time.

Patients spent most of the time taking two (on average 22.73 months) to three (on average 21.09 months) medications. While in use of mood-stabilizing drug (e.g., lithium, carbamazepine, valproate, or lamotrigine), in $30.2 \%$ of time was necessary to associate one second mood-stabilizing drug, to improve the treatment. Moreover, even were associated, others medications. Benzodiazepines, on average, were used by 29 of the 60 months, antipsychotics by 21.37 months and antidepressants by 5.91 months. Only one of the six who used antidepressant had mood switches within a $24 \mathrm{~h}$ period. This occurred spontaneously in another six patients. Eight also switched from mania to depression or vice-versa.

Regarding the results of SCOS, seven patients presented the maximum score on item 1 (non-hospitalization), i.e. they were not admitted to a hospital at any time during the follow-up period. In all 11 patients, mean scores were $\geq 3$, corresponding to a period of hospitalization of less than 3 months in the previous 12 months. No patient received the maximum or minimum scores on item 2, which refers to social functioning. Six patients had mean scores $<3$. This score corresponds to meeting with friends at most, two or three times per month. Three of these had mean scores lower than the corresponding monthly meetings (score 2 ). With respect to item 3 (employment), although two patients had satisfactory scores (each with the maximum score during the five year period), all of the remaining patients had mean scores $<3$. This score indicates that the patient was employed most of the time in the previous year. Of these, five had mean scores lower than the corresponding working more than half of the past year, but not continuously (score 3); and one had an mean score $<1$, which corresponds to work less than half the time in the previous year.

A positive correlation was found between the total number of months of euthymia and the mean scores on item 3 of the $\operatorname{SCOS}(r=0.613, p=0.045)$. A negative correlation was found between the total number of months of depression and the mean scores on item 3 of the $\operatorname{SCOS}(r=-0.84, p=$ $0.001)$. Finally, negative correlations were found between the total number of months of euthymia and age $(r=-0.755, p=$ 0.007 ) and between the number of months of euthymia and the duration of the disorder $(r=-0.744, p=0.009)$.

\section{DISCUSSION}

The present study followed-up 11 patients with BPD type I for a period of five years. The sample consisted of severely ill patients, with a mean disease duration of more than 10 years. Moreover, almost all of the patients had a previous history of hospitalization, and two had attempted suicide at some point during their disease, although none had attempted suicide during the five year follow-up period.

The present results indicate that, despite the low rate of hospitalization over the five year follow-up period, patient evolution was generally poor. The majority of patients were symptomatic most of the time, with predominantly depressive states. These findings are consistent with previous reports ${ }^{3-5,10}$. All of the patients had psychotic symptoms, and seven had experienced both manic and depressive episodes within the same day. Additionally, the majority of patients had poor social and occupational functioning, which is also consistent with previous reports ${ }^{3,10-13}$.

The present study was conducted in an outpatient department at a university teaching hospital, which is connected to an infirmary for short-term hospitalization. A healthcare unit with these characteristics often receives referrals of severely ill patients, which may explain the unsatisfactory disease course found in the majority of patients in this sample. Notably, however, these patients received appropriate, uninterrupted treatment throughout the study period. Conversely, a large proportion of individuals who suffer from BPD presents low treatment compliance ${ }^{14}$. In such cases, disease progression may be even worse. This might have been the case for several patients who began but interrupted their treatment and thus failed to meet the inclusion criteria for this study.

The present findings also suggest an inverse relationship between occupational functioning and symptom duration, especially periods of depression, a result that was reported in other studies ${ }^{3,12,13}$. Moreover, BPD prognosis tended to be less satisfactory in older patients. This latter finding corroborates the observation that the affective episodes in BPD become more chronic and less responsive to treatment over time ${ }^{15}$.

In this preliminary study, the disease course of BPD patients was evaluated over a relatively long period of time, and symptomatology assessment was performed monthly. Nevertheless, the main limitation of the study was the small sample size. Therefore, these findings must be interpreted with caution. Further studies with larger sample sizes should be performed to obtain a more accurate view of the evolution of this mental disorder

\section{CONCLUSION}

Despite the small sample size, the present findings appear to corroborate previous studies on the evolution of BPD. Most of the patients had a poor disease course, with long symptomatic periods, particularly depressive episodes, and significantly impaired social and occupational functioning. 


\section{REFERENCES}

1. Trede K, Salvatore P, Baethge C, Gerhard A, Maggini C, Baldessarini RJ. Manic-depressive ilness: evolution in Kraeplin's textbook, 1883-1926. Harv Rev Psychiatry. 2005;13:155-78.

2. Bottlender R, Strauss A, Möeller HJ. Social disability in schizophrenic, schizoaffective and affective disorders 15 years after first admission. Schizophr Res. 2010;116:9-15.

3. Rosa AR, Reinares M, Franco C, et al. Clinical predictors of functional outcome of bipolar patients in remission. Bipolar Disord. 2009;11(4):401-9.

4. Judd LL, Akiskal HS, Schettler PJ, Endicott J, Maser J, Solomon DA, et al. The long-term natural history of the weekly symptomatic status of bipolar I disorder. Arch Gen Psychiatry. 2002;59(6):530-7.

5. Post RM, Denicoff KD, Leverich GS, Altshuler LL, Frye MA, Suppes TM, et al. Morbidity in 258 bipolar outpatients followed for 1 year with daily prospective ratings on the NIMH life chart method. J Clin Psychiatry. 2003;64(6):680-90.

6. American Psychiatric Association. Diagnostic and Statistical Manual of Mental Disorders, 4th Edition: Primary Care Version. Washington DC: American Psychiatric Association; 1995.

7. First MB, Spitzer RL, Gibbon M, Williams JBW. Structured Clinical Interview for DSM-IV Axis Disorders: Clinician Version. Washington DC: American Psychiatric Press; 1997.

8. Spearing MK, Post RM, Leverich GS, Brandt D, Nolen W. Modification of the Clinical Global Impressions (CGI) Scale for use in bipolar illness (BP): the CGI-BP. Psychiatry Res. 1997;73(3):159-71.
9. Strauss JS, Carpenter WT Jr. The prediction of outcome in schizophrenia: I. Characteristics of outcome. Arch Gen Psychiatry. 1972;27(6):739-46.

10. Judd LL, Akiskal HS, Schettler PJ, Endicott J, Leon AC, Solomon DA, et al. Psychosocial disability in the course of bipolar I and II disorders. A prospective, comparative, longitudinal study. Arch Gen Psychiatry. 2005;62:1322-30.

11. Judd LL, Schettler PJ, Solomon DA, Maser JD, Corywell W, et al. Psychosocial disability and work role function compared across the long-term course of bipolar I, bipolar II and unipolar major depressive disorders. J Affect Disord. 2008;108:49-58.

12. Altshuler LL, Post RM, Black DO, Keck PE, Nolen WA, Frye MA, et al. Subsyndromal depressive symptoms are associated with function impairment in patients with bipolar disorder: results of a large, multiside study. J Clin Psychiatry. 2006;67:1551-60.

13. Marangell LB, Dennehy EB, Miyajara S, Wisniewskin SR, Bauer MS, Rapaport MH, et al. The functional impact of subsyndromal depressive symptoms in bipolar disorders: data from STEP-BD. J Affect Disord. 2009;114:58-67.

14. Perlis RH, Ostacher MJ, Miklowitz DJ, Hay A, Nirenberg AA, Thase ME, et al. Clinical features associated with poor pharmacologic adherence in bipolar disorder: results from the STEP-BD study. J Clin Psychiatry. 2010;71(3):296-303.

15. Berk M, Hallam K, Malhi G, Henry L, Hasty M, Macneil C. Evidence and implications for early intervention in bipolar disorder. J Ment Health. 2010;9(2):113-26. 